preliminary laboratory trials in 1904, which gave about $7 \mathrm{~km}$. per second for the drift, the apparatus was transferred to the Cleveland Heights and set up in a temporary hut surrounded with glass windows, at an altitude of 285 metres; and trials in October 1905 gave a velocity of $8.7 \mathrm{~km}$. $/ \mathrm{sec}$. for the drift.

Shortly after this, Prof. Morley retired, but plans had been made for further trials, and in 1921 the interferometer was set up in a hut in the grounds of the Mount Wilson Observatory at an altitude of 1,750 metres, and surrounded with canvas windows. Trials were carried out in April 1921 and indicated a maximum drift of $10 \mathrm{~km}$./sec. Before this result was announced, a careful series of tests was made concerning the possible effects of temperature changes, loading, magnetisation and magnetostriction, and centrifugal and gyrostatic forces. A cross of concrete reinforced with brass was then made up so as to eliminate any possible magnetic effects, and gave similar results in December 1921. As this cross, although heavier, was less rigid than the steel one, the latter was reverted to; and, after further optical improvements had been made at Cleveland, the apparatus was again set up at Mount Wilson in a hut on a new site, with all the refinements previous experience had suggested. Trials made in September 1924 gave the same value of $10 \mathrm{~km}$. $/ \mathrm{sec}$. for the drift.

(To be continued.)

\title{
Science and Food Supplies
}

A NUMBER of topics came under discussion $A$ at the recent symposium on food preservation held by Section I (Physiology) on September 11 during the annual meeting of the British Association at Aberdeen, and a wealth of information and suggestion of biochemical and physiological interest was forthcoming from the authors of the papers. In general, the communications were in fact far too condensed and obviously represented an attempt, which we understand was made at request, to provide a review of the underlying problems of food preservation.

\section{Muscle Proteins}

Two of the most interesting problems which are at present to the fore in the study of post-mortem changes in muscle proteins are those of lactic acid formation and of protein denaturation. In the view of Drs. T. Moran, G. A. Reay and E. C. Smith, lactic acid formation is governed by the concentration of salt, the same general relations being obtained whether salt concentration is varied (1) by drying intact muscle, (2) by freezing intact muscle, or (3) by adding salt to suspensions of minced muscle. The salt concentration which determines maximum rate of lactic acid formation is that which determines maximum solubility of the myosin (saltsoluble) fraction of the muscle proteins, and hence it is suggested that an intimate relation must exist between this protein and the enzyme substrate complex responsible for lactic acid production. It is the salt concentration obtained by freezing muscle to equilibrium at $-2^{\circ}$ to $-3^{\circ} \mathrm{C}$.

In the study of denaturation, care must be taken that there is nothing in the technique itself which may render the protein insoluble. Toluene as a temporary preservative, for example, must be avoided. Although it has been claimed that so much as 70 per cent of the proteins of muscle are rendered insoluble within twenty-four hours of death, more critical methods show that rigor mortis is not accompanied by appreciable denaturation. The conditions which promote maximum denaturation in subsequent storage have been found to be similar to those which promote maximum solubility ; for example, the rate of denaturation in frozen meat or fish is at a maximum at $-2^{\circ}$ to $-3^{\circ} \mathrm{C}$.

Prior to this recent work on protein denaturation, it was thought that the only factor influencing 'drip' from thawed-out frozen flesh and loss of quality during cold storage was the rate of freezing, which determined the number, size and position of the ice crystals. It is now clear that protein denaturation plays an important part, and is in addition the principal factor responsible for the 'dryness' and loss of quality of meats and fish preserved by freezing. Guided by this new knowledge, great progress is now being made in the fishing industry. Both quick freezing and subsequent holding at low temperatures are being employed in order to reduce denaturation to the greatest extent possible.

\section{Life-Duration of Fruits}

The preservation of fresh fruit presents an entirely different set of problems. In their discussion of these problems, Drs. F. Kidd and C. West stated that the fundamental issue is the question of life-duration and of the factors determining it. Analysis has shown that race, nutrition and environment are the principal determinants : and further, that the respiratory activity per cell unit of the crganism appears to be an integrated expression of the influence of these factors upon life-duration. The higher the pitch of activity, the shorter the life and vice versa. Death of the organisms after separation from the tree is not, however, simply due to exhaustion of sugar reserves. "If we may take a mechanical analogy, 
the ageing and death of the fruit seems to be related rather to the wearing out of the machine by use than to the failure of its fuel reserves."

An interesting experiment described was one in which the life-duration of apples gathered at different stages of their growth from June onwards was determined. Maximum life-duration was exhibited by young fruits of about walnut size. Cell division had ceased in these fruits and the major enlargement by increase in cell size and storage of sugars had not taken place. It is at this stage that they exhibit minimum respiratory activity per cell unit.

Respiratory activity after gathering is subject to control by varying the temperature and the composition of the atmosphere. In either case, reciprocal effects on life-duration are obtained. The effects of oxygen and carbon dioxide concentration are new, and while still subject to analysis, have already been widely applied industrially in the fruit industry.

\section{Composition of Fish Fats}

A considerable amount of new ground has been broken recently in regard to the composition and physiology of fish fats. The position was reviewed, especially in the light of his own work at the Torry Research Station, by Dr. J. A. Lovern. As a class, fish fats are characterised by a greater number of individual fatty acids than are found in land animals: further, there are noticeable differences in the fats laid down by fresh-water and marine species. It appears that, in general, the peculiarities in the composition of fish fats can be traced back through the dietary chain from large carnivorous fishes to the vegetable feeding copepods. Curiously, however, in the case of the young salmon, its fat changes from the fresh-water type to the marine type while the fish is still in fresh water.

In laying down their fat reserves, there is, in the case of many fishes possessing more than one fat depot, a marked selectivity as between these depots. This selection appears to be governed by molecular size. In the mobilisation of fats for transference to the gonads, there is no evidence of selection as between depots, nor can evidence be obtained that the liver is active in desaturating fats as a preliminary to their oxidation, for in many cases the liver fats are found to be more saturated than the depot fats.

F. K.

\section{The Mendeléeff Centenary and Scientific Progress in the U.S.S.R.}

$\mathrm{A}^{\mathrm{N}}$ international congress in honour of the hundredth anniversary of Mendeléeff's birth was held last September in Leningrad with a splendour appropriate to his importance as the greatest Russian man of science. The official list mentioned 'delegates' from many countries. As, however, the Russian Academy of Science had preferred to send personal invitations to scientific workers abroad instead of requesting societies and associations to send their representatives, we should more properly describe those who took part in the congress as guests. There were 26 foreign participators and about 300 official Russian delegates, besides some 1,400 unofficial Russians, who attended the lectures.

In planning the congress, the Russian Government set out not only to pay tribute to Mendeléeff's memory, but also to give the members an idea of the present-day position of Russian science and industry, so far as was possible within a fortnight. Therefore the lectures more or less closely connected with Mendeléeff and his work took place in the first part of the session. In connexion with it there followed inspections of scientific institutes in Leningrad, Moscow and Kharkov, and a visit to the industrial works at Dnjeproges.

The congress began on September 10 with a ceremonial inauguration in the former Taurian
Palace in Leningrad, in the hall in which the Duma used to meet. It was specially impressive that welcome to those taking part was uttered not only by the president of the Academy and some high Soviet officials, but that at the end of the first meeting the platform was taken by twenty or thirty workmen in their workingclothes, whose speaker bid the congress welcome in the name of the engineers and chemical workers of Leningrad, and expressed their appreciation of Mendeléeff's life work for the industrial development of Russia. In consequence of the manner in which the invitations had been sent out, there were no addresses from foreign societies. Only the Royal Society of London, which had specially close relations with Mendeléeff, sent greetings by one of its fellows, Prof. J. W. McBain (Stanford University).

The first lectures were devoted to Mendeléeff's memory. In consideration of foreign delegates, some of the Russians spoke in French, or at least repeated from time to time the essential gist in a few sentences in French. Nevertheless, foreign visitors were mostly dependent on the printed synopses or the kindly translations of colleagues for their understanding of the Russian contributors, and therefore lost many details. Prof. Bajkov gave a description of Mendeléeff's scientific work. Prof. Ivanov dealt with Mendeléeff's 